\title{
PENGARUH PENERAPAN TEKNOLOGI INFORMASI TERHADAP \\ KEBUTUHAN DIKLAT GURU SMK BIDANG BISNIS DAN \\ PARIWISATA
}

\author{
Oleh: Tri Agus Siswanto, S.Pd,MM
}

Triagus_04@yahoo.com

\begin{abstract}
Abstrak
Penerapan sistem informasi pada lembaga bisnis saat ini telah menjad kebutuhan dalam nerebut pasar global yang semakin pesat, baik perangkat hardware maupun software dengan fasilitas jaringan internet, seolah-seolah membuat semua orang dalam segala bidang dapat mengetahui informasi apa saja yang mereka inginkan dengan cepat dan mudah. Sementara itu seiring dengan lajunya gerak pembangunan, organisasi-organisasi publik maupun swasta, baik di bidang bisnis maupun pariwisata semakin banyak yang mampu memanfaatkan teknologi informasi terbaru, yang dapat menunjang efektivitas, produktivitas dan efesiensi usahanya. Berkat kemajuan teknologi komunikasi dan informasi, pesan-pesan dapat dikirim dan diterima pada waktu yang bersamaan meskipin jarak antara pengirim dan penerimanya demikian jauh, arus informasi dalam kehidupan manusia modern tidak mungkin lagi di batasi.
\end{abstract}

\section{Kata Kunci: Teknologi,Diklat,Pariwisata}

\section{A. Latar Belakang Permasalahan}

Di era globalisasi sekarang ini para manajer professional telah banyak yang memanfaatkan keunggulan dari penerapan teknologi informasi, hal ini dikarenakan hasil dari data atau transaksi perusahaan dapat di peroses melalui alat bantu teknologi informasi atau komputerisasi sehingga menghasilkan laporan atau informasi yang relevan untuk pengambilan keputusan, akurat dalam hasil hitungannya sehingga tidak meyesatkan, ketepatan waktu dalam

\footnotetext{
${ }^{4}$ Dosen Program Studi Sekretari Fakultas Ekonomi Universitas Pamulang
} 
menyajikan data secara lengkap sehingga manajemen sangat terbantu dalam pengambilan keputusan.

"Internet banyak menolong dalam penelitian tugas akhir. Tukar menukar informasi atau Tanya jawab dengan pakar dapat dilakukan melaui intetnet .Tanpa adanya internet banyak tugas akhir atau thesis yang mungkin membutuhkan waktu yang lebih banyak, untuk diselesaikan kerjasama antar pakar dan juga dengan mahasiswa yang letaknya berjauhan secara fisik dapat dilakukan dengan mudah. Dahulu seorang harus berkelana atau berjalan jauh untuk menemui seorang pakar untuk mwndiskusikan sebuah masalah.Saat ini hal ini dapat dilakukan dari rumah dengan mengirimkan email. Makalah dan penelitian dapat dilakukan dengan saling tukar menukar data melalui internet, via email, atau pun dengan menggunakan mekanisme file sharing.Bayangkan apa bila seorang mahasiswa di irian dapat berdiskusi masalah kedoktetan dengan seorang pakar di Universitas terkemuka di pulau Jawa.Mahasiswa dimanapun di indonesia dapat mengakses pakar atau dosen yang terbaik di indonesia dan bahkan di dunia. Batasan geografis bukan menjadi masalah lagi."Budi.insane.co.id (2000:1)

Sharing information juga sangat dibutuhkan dalam bidang penelitian agar penelitian tidak berulang (reinvent in the wheel) . Hasil-hasil penelitian di perguruan tinggi dan lembaga pendidikan dapat digunakan bersama-sama sehingga mempercepat proses pengembangan ilmu dan teknologi.

Distant learing dan virtual university merupakan sebuah aplikasi baru bagi internet. Bahkan tak kurang pakar ekonomi petet Drucker mengatakan bahwa "Tringgered by the intetnet, continuing adult education may well become oaur greatest growth industry". Virtual University memiliki karakteristikyang scalable, yaitu dapat menyediakan pendidikan yang diakses oleh orang banyak. Jika pendidikan hanya dilakukan dalam kelas biasa, berapa jumlah orang yang dapat ikut serta dalam satu kelas?. Jumlah peserta mungkin hanya diisi 50 orang . Virtual University dapat diakses tanpa membatasibjumlah peserta oleh siapa saja, dari mana saja. 


\section{B. Pokok Permasalahan}

Seperti telah di jelaskan dalam latar brlakang, bahwa inti dari diselenggarakanya program diklat adalah adanya upanya untuk menutupi kesenjangan, dalam hal ini difokuskan padapenerapan teknologi informasi yang selalu berkembang dengan cepat dan telah di terapkan di lembaga bisnis dan lembaga pemerintahan.

Dengan materi yang diberikan oleh lembaga diklat saat ini,yang biasanya berdasarkan kurikulum suplay driven yang masa berlakunya sudah lama sehingga memerlukan penyesuaian materi.

Dengan demikian untuk memenuhi tuntutan perkembangan tersebut Pusat Pengembangan Penataran bagi guru SMK bidang sains dan pariwisata berkewajiban untuk memberikan materi yang sekiranya telah menjadi tuntutan standar kopetensi yang berlaku di dunia kerja.

Karena guru SMK yang secara langsung akan membekali siswa yang nantinya dituntut untuk memiliki kompetensi/ketrampilan kerja yang dibutuhkan oleh dunia kerja yang berlaku saat ini.

\section{Identifikasi Masalah}

Secara garis besar jika permasalahan yang ada kita identifikasi mengapa diperlukan kebutuhan diklat, perlu terus dikembangkan agar dapat meningkatkan mutu pendidikan kejuruan di bidang sains dan pariwisata, agar dapat memenuhi kebutuhan tuntutan perkembangan pasar kerja tentu ada beberapa penyebabnya antara lain adalah :

\section{a. Kurikulum \& Perkenbangan Teknologi}

Kurikulum yang disusun oleh Departemen pendidikan Nasional umumnya berlaku mulai pada periode tertentu misalnya kurikulum tahun 1984 diperbaharui kurikulum 1994 kemudian disempurnakan tahun 1999 dan akan disusun lagi kurikulum tahun 2004. Maka jika kita perbandingkan dengan perkembangan teknologi yang begitu cepat, bahkan tiap tahun ada saja perkembangan baru yang lebih 
canggih, baik dari kecepatan proses maupun fasilitas baru, dan munculnya software aplikais yang baru msks kurikulum yang dirancang umumnya sepuluh tahun satu kali telah banyak mengalami ketinggalan dan kurang fleksibel dalam mengikuti perkembangan teknologi.

\section{b. Sumber Daya Manusia}

Sumber daya manusia yang berhubungan dengan lembaga pendidikan (terutama

SMK) dapat di kelompokan menjadi tiga bagian yaitu :

1) Tenaga fungsional dalam hal ini guru yang akan menyampaikan materi bidang keahlian tertentu untuk disampaikan kepada siswa,terkadang bekal mereka mengajar adalah materi yang pernah di terimanya pada saat kuliah, yang sudah cukup lama yang semestinya selalu mengembangkan diri sesuau perkembangan bidang keahliannya masing-masing.

2) Tenaga Struktural disekoalah yang berfungsi sebagai penyelenggara administratif dalam peroses belajar mengajar yang terkadang kutmrang memperhatikan maintenance/ memperbaiki fadilitad sarana \& prasarana agar tetap berfungsi, termasuk dalam pembaharuan dari penerapan Sistem administrasi pendidikan yang belum menerapkan Sistem Informasi Manajemen dengan Komputerisasi.

3) Siswa SMK sebagai masukan yang harus diproses dalam Pembelajaran untuk diberikan bekal pendidikam ketrampilan agar menjadi tamatan yang siap kerja dan bermutu, dari sisi ini biasanya siswa yang memilih SMK sebagai tempat belajar merupakan tamatan Sekolah Menengah Pertama (SMP) yang jika dilihat dari segi harapan dia tidak ingin masuk perguruan tinggi karena ingin cepat kerja dikarenakan umumnya perekonomiannya memang lemah, sehingga siswa SMK merupskan siswa lapis kedua, karena siswa yang pandai akan memilih SMU untuk pilihan utamanya. 


\section{c. Bahan Ajar/Buku-buku}

Buku-buku sebagai bahan ajar yang ada di SMK khususnya buku komputer umumnya selaku ketinggalan, karena dibuatnya mengacu ke kurikulum jika dibandingkan dengan perkembangan teknologi yang selalu berubah dengan cepat, buku yang baik dan tidak ketinggalan umumnya masih berbahasa inggris yang harganya cukup mahal dan siswa kita kurang terampil mempelajari buku bahasa inggris, walaupun cukup banyak buku komputer dalam bahasa indonesia tetapi sistem penulisannya tidak semenarik aslinya dalam bahasa inggris.

\section{d. Sarana Prasarana}

Untuk mencapai kompetensi ketrampilan kejuruan yang unggul bagi siswa SMK diperlukan peralatan praktek yang memadai, selama ini peralatan praktek di SMK khususnya yang mendukung keahlian teknologi informasi terutama komputer rata-rata masih mengalami kendala kekurangan alat praktek.

Sekalipun ada umumnya sudah ketinggalan untuk pemakaian fasilitas tertentu misalnya untuk internet tidak mampu lagi, hal ini diperparah dengan banyaknya siswa yang tak sebanding dengan jumlah alat yang ada, tidak mampunya memperbaiki sendiri alat yang rusak dan di beberapa SMK yang memiliki peralatan baru, justru tetjadi kehilangan komputer karena dibobol oleh pencuri yang tidak peduli dengan kebutuhan siswa.

\section{e. Terbatasnya dana operasi pendidikan}

Jika teknologi informasi telah menjadi pilihan yang harus di sampaikan kepada siswa, maka konsekwensinya adalah dana untuk operasional peralatan yang berhubungan dengan komputer yang harganya relatif masih mahal sedangkan kemampuan ekonomi siswa SMK umumnya tidak terlalu beradaya.

Dana yang diperlukan hubungannya dengan pemakaian praktek komputer antara lain : 
1) Investasi pertama untuk hardware dan software

2) Dan rutin untuk pembayaran suplai tenaga listrik dan pulsa telphone

3) Maintenace/perbaikan alat jika terjadi kerusakan

4) Bahan habis pakai baik berupa tinta printer dan kertas

Semua hal diatas merupakan beban yang harus di pertimbangkan dalam belajar mengajar yang direncanakan dengan seksama pada penyusunan anggaran operasional sekolah.

\section{f. Software aplikasi yang beragam}

Dalam dunia kerja terutama lembaga bisnis, komputer telah banyak dipergunakan untuk berbagai fungsi yang berbeda, sehinggga patra pekerja dituntut untuk memiliki keahlian yang diperlukan sesuai dengan bidangnya masing-masing. Dalam rangka memenuhi hal tersebut siswa SMK perlu dibekali keahlian yang memadai agar setelag tamat dapat menerapkan keahliannya sesuau tuntutan yang diperlukan, masalahnya adalahg sudah mampukah tamatan SMK sekarang ini untuk mengoprasikan komputer dalam era teknologi informasi ini sesuai tuntutan komputer standar dunia kerja ? fungsi pokok dalam lembaga bisnis umumnya dibagi menjadi beberapa bagian yang semuanya dapat menggunakan komputer untuk memperoses data transakdi perusahaan diantaranya adalah :

1) Bagian produksi atau operasional sebagian besar telah menggunakan komputer untuk pengolahan data perhitungan pengumpulan biaya operasional/biaya produksi, baik perhitungan pemakai bahan baku sistem penggajian tenaga kerja dan biaya overhead lainnya dengan software manuafakturing. 
2) Bagian pemasaran yang telah menerapkan komputer sebagai sistem pemasaran yang baik pemasangan iklan di situs web yang telah dibuat ataupun menangani order penjualan, dengan menerapkan Emarketing, E-mail maupun E-busines

3) Bagian administrasi dan umum telah memanfaatkan sistem filing/arsip dalam mengelola berkas secara komputerisasi dan surat menyurat dengan elektronik mail (E-mail)

4) Bagian akuntasi telah dituntut untuk memperoses data keuangan dengat cepat, akurat dan tepat waktu, untuk itu pemerosesan data telah di pakai komputerisasi yang umumnya berupa program aplikasi akuntansi aik diuat sediri ataupun tailor made sesuai dengan sfat dan cir transaksi di perusahaan pengguna, bahkan dalam pelayanan pulik sudah otomatis dalam pelayanannya tanpa anyak pegawai seperti yang diterapkan dalam peraikan dengan menggunakan kartu ATM (Automatic Teller Machine) dalam hal ini sudahkah guru dan siswa dibekali ketrampilan terseut sehingga siap menghadapi tuntutan kebutuhan dunia kerja?

Tabel : 1

Daftar harga software dari Microsoft untuk institusi

\begin{tabular}{|l|c|}
\hline Descripton & Unit Price \\
& US\$ \\
\hline Office P Standard Win32 English Disk Kit & 26 \\
\hline $\begin{array}{l}\text { Office P Standard Win32 English OLP NL } \\
\text { AE }\end{array}$ & 55 \\
\hline \multicolumn{1}{|c|}{} & 26 \\
\hline Office P Pro Win32 English Disk Kit & 66 \\
\hline Office P Pro Win32 English OLP NL AE & 26 \\
\hline Office P Professional Win32 English Disk & \\
\hline
\end{tabular}




\begin{tabular}{|l|c|}
\hline Kit & \\
\hline Office P Professional Win32 English OLP & 70 \\
NL AE & \\
\hline & \\
\hline *Note: Minimum requirement 5 licens & \\
\hline
\end{tabular}

\section{Rumusan Masalah}

Dari latar belakang yang telah dkemukakan diatas dapatlah diidentifikasi permasalahan seagai berikut " Bagaimana pengaruh penerapan teknologi informasi dan fungsi pokok lembaga bisnis terhada keutuhan diklat guru SMK khsusnya bidang isnis dan pariwisata pada pusat pengembangan penataran Guru kejuruan Jakarta".

\section{E. Tujuan dan Manfaat penelitian}

\section{Tujuan Penelitian}

Penelitian in bertujuan untuk mengetahui dan menjelaskan sejauh mana pengaruh penerapan teknologi informasi/Komputerisasi pengolahan data bisnis masa kini telah direspon oleh diklat di PPPG kejuruan untuk menatar guru-guru pada sekolah menengah kejuruan (SMK) khsusnya bidang bisnis dan pariwisata dan sejauh mana kebutuhan diklat dipersiapkan untuk mengantipasi perkemangan teknologi yang sangat pesat.

\section{Manfaat Penelitian}

\subsection{Manfaat agi dunia praktis}

Dari hasil penelitian ini diharapkan dapat dimanfaatkan sebagai sumbangan masukan informasi yang dapat dijadikan salah satu dasar agi kepala pusat pengembangan penataran guru kejuruan jakarta, untuk menyesuaikan program materi diklat yang dapat memberikan kontribusi yang positif terhadap kemajuan sekolah menengah kejuruan. Khususnya idang bisnis dan pariwisata sesuai dengan keutuhan teknologi informasi yang dibutuhkan oleh 
dunia usaha saat ini, dengan keterampilan yang berkompetensi baik yang berstandar nasional maupun internasional.

\subsection{Manfaat terhadap kpentingan Dunia Akademis}

Penelitian ini diharapkan dapat digunakan sebagai bahan pertimangan bagi rekan-rekan mahasiwa dalam melakukan

penelitian yang dilakukan di waktu yang akan datang,khususmya yang erkatan dengan masalah penerapan system informasi manajemen pada lemaga diklat. Selain itu dapat dijadikan sebagai bahan bacaan bagi rekanrekan mahasiswa administras bisnis khususnya program studi manajemen ekonomi pulik, yang sedang melakukan penelitian yang erkaitan dengan system informasi manajemen.

\section{F. Pemahasan}

\section{Hakekat fungsi pokok lembaga bisnis}

Didalam menjalankan kegiatannya suatu lemaga bsinis biasanya dipimpin oleh seorang direktur dan dibantu oleh beberapa agian penting yang masingmasing agian mempunya fungsi yang berbeda dan saling mendukung didalam mencapai tujuan perusahaan. Menurut Wing Wahyu Winarno (1994 : 6) dalam ukunya sistem informasi akuntasi STIE YKPN Yogyakarta sistem informasi manajemen terdiri dari berbagai sub system, sub system yang sudah banyak diterapkan dalam suatu perusahaan antara lain adalah :

1. Sistem informasi pemasaran (Marketng Information Sstem)

2. Sstem informasi personalia (Personal informaton sistem )

3. Sistem informasi akuntansi(Accounting information system )

4. Sistem informasi kantor(Office otomation) 


\section{Sistem informasi aktiva}

Dari uraian di atas system nformasi dibagi dalam beberapa susistem yang sangat disesuaikan dengan keutuhan manajemen akan informasi yang sangat bervariasi tidaklah mungkin penuh oleh satu jenis system informas saja. Selain itu system informasi manajemen sangat luas pengertian dan ruang lingkupnya, sehingga diperlukan sumer daya yang tidak sedkit untuk menyusunya, oleh karena itu perlu dibagi dalam beberapa jenis system informasi yang lebih sempit, berbagai system informasi terseut harus saling terkait, saling mendukung dan saling bekerja sama sehingga mementuk suatu system yang utuh yang leih besar.

Lebih lanjut Wing winarno (1994:7) menyatakan "salah satu system informasi yang banyak diperlukan oleh perusahaan atau organisasi adalah system informasi akuntansi, yang disusun untuk mengumpulkan data akuntansi dan pengolahannya menjadi informasi akuntansi, yang kelak akan digunakan oleh manajemen untuk bahan pengambilan keputusan. Sebagai suatu system yang cukup esar system informasi akuntansi mempunyai beberapa sub system atau komponen diantaranya adalah :

a. Sistem pembelian (purchasing)

b. Sistem penjualan(sales order processing)

c. Sstem piutang dagang(account receivable)

d. Sistem utang dagang(account payable)

e. Sistem pengawasan persediaan(inventory control )

f. Sistem pengajian(payroll)

g. Sistem buku besar(general ledger)

h. Sistem akuntansi biaya(cost accounting)

i. Sistem akuntansi pertanggung jawaban(responsiility)

Mulyadi (2000:7) Adapun fungsi-fungsi pokok yang terdapat dalam perusahaan manufaktur adalah fungsi-fungsi produksi, administrasi dan umum, daan fungsi pemasaran, sehingga biaya-biaya dalam perusahaan 
manufaktur dapat digolongkan menjadi biaya produksi, iaya administrasi dan umum serta biaya pemasaran

\section{Fungsi Produksi/operasional.}

Mulyadi (2000:7) Dalam perusahaan manufaktur/industri fungsi produksi adalah salah satu bagian dalam perusahaan industri yang fungsi pokoknya berhubungan dengan proses pengolahaan bahan baku menjadi produk jadi. Biaya produksi diagi tiga elemen (biaya bahan baku,biaya tenaga kerja dan biaya overhead parik).

Dari pengertian terseut diatas karena kompleksitasnya biaya produksi pengolahan produk tertentu untuk bisa dijual memerlukan

penanganan yang cermat, tepat waktu dan akurat, dalam era teknologi biasanya sudah dikerjakan dengansystem komputerisasi untuk menangani berbagai elemen biaya produksi agar manajemen dapat menggunakan informasi sebagai pengambilan keputusan, untuk itu perlu dipersiapkan tenaga operator komputer yang sekaligus mengetahui konsep dasar akuntansi melalui pendidikan formal ataupun informal, sehingga standar komputerisasi terpenuhi.

\section{Fungsi Administrasi}

Fungsi administrasi dan umum dalam hal ini, dimaksudkan untuk penanganan kegiatan dalam hubungannya dengan kegiatan-kegiatan yang tidak dapat diidentifikasi dengan aktivitas produksi maupun pemasaran. Biaya yang timbul dalam hubunganya dengan kegiatan administrasi dan umum, adalah biaya yang terjadi dalam hubungannya dengan penyusunan kebijaksanaan dan pengarahan perusahaan secara keseluruhan. Contoh dari biaya administrasi dan umum adalah : Gaji direksi,b biaya bagian akuntansi dan personalia, biaya pengiriman surat, arsip,biaya rapat bpemegang saham, gaji eksekutif, biaya tilpun dan lain-lain (Mulayadi 2000:7). 
Dalam perkembangannya pengolahan data administrasi pada lembaga bisnis telah mengalami banyak pekembangan baik cara menangani pengiriman surat, system pengarsipan (filling) dan pemerosesan data lainnya. Seperti halnya pengiriman surat sekarang akan lebih cepat dan efesien dengan diterapkanya elektronik mail (E-mail) sebagai saran pengirimannya. Juga dalam system pengarsipan tidak lagi harus disimpan dalam bentuk fisik dengan rangkap dalam almari karena sudah dipakai system file menggunakan teknologi informasi yang cocok seperti database manajemen system (DBMS), sehingga lebih memudahkan ununtuk mencari data yang diperlukan hanya dengan beberapa perintah dalam menu pencarian maka apa yang diperlukan dapat ditemukan.

\section{Fungsi Pemasaran}

Pengertian pemasaran menurut Kotler (1997:8) pemasaran adalah:

"Suatu proses sosial dan manajerial yang didalamnya individu-individu dan kelompok untuk mendapatkan apa yang mereka butuhkan dan inginkan dengan menciptakan, menawarkan dan mempertukarkan produk yang bernilai dengan pihak lain".

Sedangkan pengertian manajemen pemasaran menurut Kotler (1997:20) ‘ Manajemen pemasaran adalah analisis, perencanaan,penerapan, dan pengendalian terhadap program yang direncanakan untuk menciptakan,membangun,dan mempertahankan pertukaran dan hubungan yang menguntungkan dengan pasar sasaran dengan maksud untuk mencapai tujuan-tujuan organisasi’.

Dari batasan pemasaran tersebut di atas dapat dipahami bahwa bahwa arti pemasaran bertumpu pada konsep kebutuhan,keinginan,permintaan produk,pertukaran,transaksi dan pasar dengan demikian pemasaran terjadi bilamana orang memutuskan kebutuhan dan keinginan melalui pertukaran 
E-Marketing merupakan strategi marketing ataub pemasaran online melaui internet dalam bisnis global seperti search engine,email,dan lain-lain.

Onno W. Purbo, (2001:36) Mengenal eCommerce, Jakarta Elex media Komputindo, E-Commerce is a dynamic set of tecnologies. Applications, and business process that link enterprice,consumers, adn commuties through electronic transcation and the electronic exchange of goods,services, and information'. Jadi ecommerance merupakan satu set dinamis teknologi,aplikasi,dan proses bisnis yang menghubungkan perusahaan,konsumen,dan komunitas tertentu melalui transaksi elektronik dan perdagangan barang, pelayanan, dan informasi yang dilakukan secara elektronik. Mengapa ecomerce menjadi topik pembicaraan hangat dan mengubah trend kehidupan saat ini ke arah itu,hal ini disebabkan karena keuntungan yang dapat diambil sengan adanya penerapan ecomerce.

Menurut Onno W. Purbo (20012:3)

1) Revenue stream (aliran pendapatan) baru yang mungkin lebih menjanjikan, yang tidak bisa ditemui di sistem transaksi tradisionil.

2) Dapat meningkatkan market exposure (pangsa pasar)

3) Menurunkan biaya operasional

4) Melebarkan jangkauan (global reach)

5) Meningkatkan customer loyality

6) Meningkatkan suplier manajemen

7) Memperpendek waktu produksi

8) Meningkatkan value chaim (mata rantai pendapatan)

Secara umum ecomerce dapat diklasifikasikan menjadi dua jenis, yaitu Business to (B2C), yang menjadi perbedaan kedua jenis ecomerace adalah sebagai berikut : Kegiatan yang berhubungan dengan ecomerce dunia teknologi berkembang semakin canggih, perkembangan tersebut secara langsung maupun tidak langsung mempengaruhi sistem perdagangan, transaksi dan peredaran uang yang dilakukan manusia selama ini. Sebelumnya transaksi secara tradisional dilaksanakan dari tangan ke tangan secara langsung, antara pembeli dan penjual bertatap muka, 
melakukan persetujuan dan akhirnya terjadi kesepakatan. Namun kini dengan adanya kecanggihan teknologi komputer, semua keterbasan saran, jarak dan waktu transaksi dapat teratasi dengan mudah. Hanya dengan klik saja kita bisa mendapatkan barang yang diinginkan, bisa mengetahui apa-apa yang kita dinginkan, bisa mengetahui apaapa yang kita inginkan, dan dapat melakukan transaksi dengan siapa saja tanpa dibatasi oleh waktu dan jarak. Kemudahaan inilah yang menjadi faktor utama berkembangnya eCommerce.

Ketepatan (akurasi), Kemudahaan, dan kecepatan menjadi ciri kegiatan eCommerce : Kegiatan-kegiatan yang dapat dilakukan dengan eCommerce :

1) Perdagangan online melaui world wide web (Pc-Perconal Computer) merupakan contoh yang paling mudah dan umum dipakai oleh masyarakat.

2) Transaksi online bisnis antar perusahaan

3) Internet banking yang saat ini sedang berkembang di indonesia, dimana kita nanti bisa mengecek melalui internet beberapa saldo kita, mengganti nomor PIN ATM kita,transfer antar rekening, dan berbagai macam kemudahan sistem pembayaran tagihan lainnya. Semua itu dikembangkan tidak lain hanya untuk memudahkan manusia dalam menjalankan aktivitas sehari-hari yang semakin padat dan sibuk.

4) Televisi. Interaktif dimana melalui televisi kita bisa melihat daftar acara secara interaktif,internet lewat TV, dan akses web lewat TV. Sudah lebih dari delapan juta otang di eropa telah memiliki akses ITV (Interaktive Television)nini. Dan diperkirakan pada tahun 2003, jumlah ini akan bertambah menjadi 40 juta pelanggan.

5) WAP (Wireless Application Protocol) juga menjadi trend yang tak kalah menarik di kalangan sistem belanja online. Bahkan hanya dengan handphone yang selalu ada di saku kita, dapat melakukan segala macam transaksi yang kita inginkan. Mulai dengan pembelian tiket pesawat terbang, memesan makanan di restoran, maupun kesepakatan transaksi bisnis lainnya. Hal ini dapat kita amati dari maraknya agen penjualan handphone berbagai pinggiran 
jalan yang menandakan menjadikan pilihan masyarakat sebagai saran berkomunikasi.

Konsep dasar dari cara kerja eCommerce adalah diawali dengan konsumen berbelanja secara online melalui internet, seperti yang diterapkan pada toko buku amazone. Dalam internet itulah mulai berbelanja barang yang diinginkan, untuk itu mulailah dia memasuki server transaksi online di mana semua informasi yang dia berikan untuk keperluan belanja online di enkripsi. Kemudian dia memesan sebuah order, segala yang berkaitan dengan order ini dikirim melalui sebuah jaringan pintu gerbang rahasia (provate gateway) ke bagian pemerosesan informasi (processing network) disinilah transaksi sinyatakan syah atau tidak syah, oleh banyak yang bersangkutan sebagai penentu proses verivikasi adanya sumber dana atau layak tidaknya transaksi di lanjutkan.

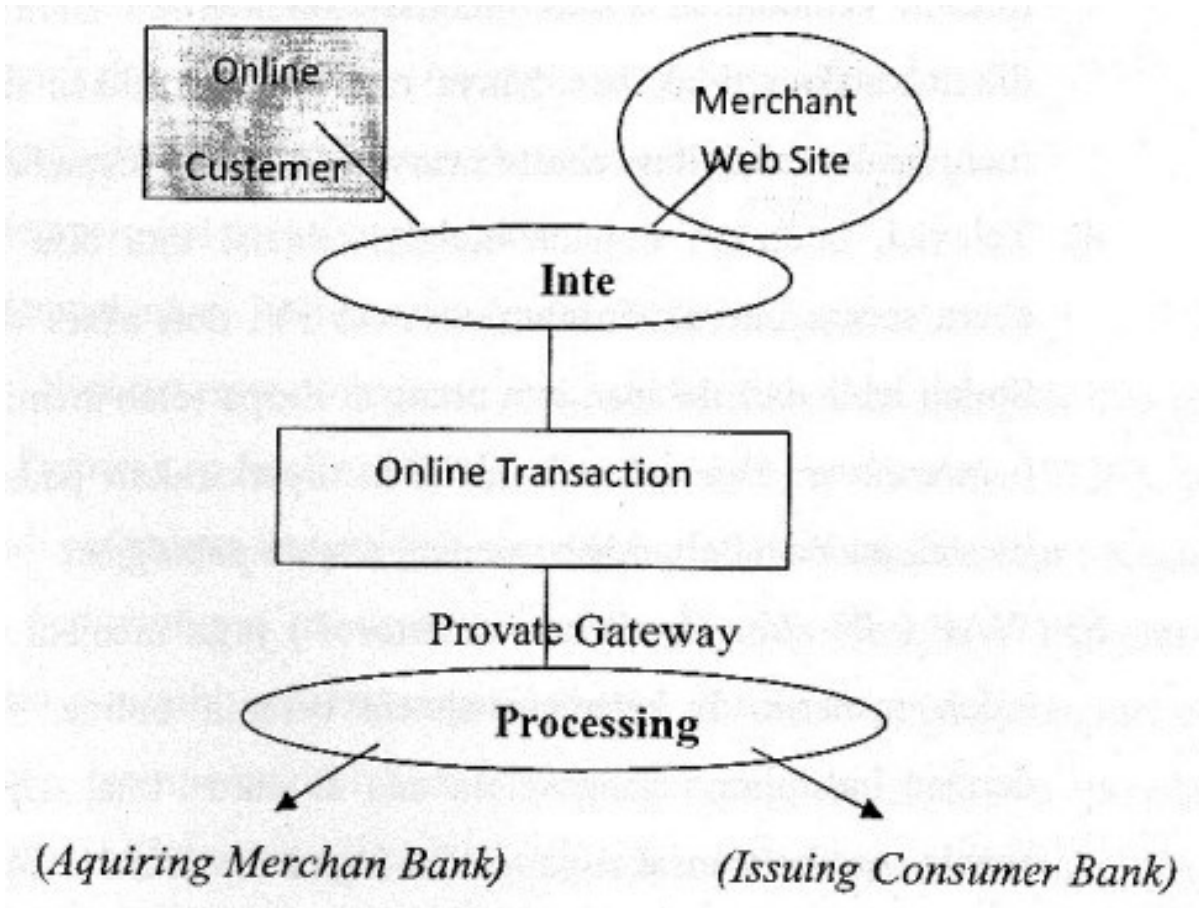

\section{Gambar 2 : peta eCommerce}

Sumber : onno W. Purbo (2001:139) mengenal eCommerce, Jakarta Elex media

\section{Fungsi Keuangan/Akuntansi}

Menurut Wing Wahyu (1994:9): 
"Fungsi dari bagian keuangan atau akuntansi adalah mengupayakan berjalannya sysyem akuntansi yang diterapkan dalam perusahaan yang meliputi seperangkat catatan, prosedur dan peralatan yang secara rutin berhubbungan dengan peristiwa yang mempengaruhi prestasi dan posisi keuangan suatu organisasi. Sistem akuntansi memusatkan perhatian pada transaksi yang berulang (reperitif) dan jumlahnya material".

\section{Kurikulum Diklat}

Pengertian kurikulum menurut Nanang Fattah (2000:14) "Kurikulum merupakan komponen ilmu pendidikan yang berkenaan dengan tujuan dan bahan acuan interaksi, baik yang bersifat ekplisit maupun implicit tersembunyi".

Teori yang dikembangkan dalam komponen ini meliputi antara lain , teori tentang tujuan pendidikan, organisasi kurikulum, isi kurikulum, dan modul-modul pengembangan kurikulum.

Dalam merencanakan sebuah kurikulum pendidikan dan pelatihan yang berdasarkan kompetensi titik awalnya adalah standar kompentensi yang relevan. Menurut Subandi(2002:8), dalam penyiapan program diklat perlu adanya BPP (Garis-garis Besar Program Pembelajaran), yang dapat digambarkan dalam skema berikut ini :

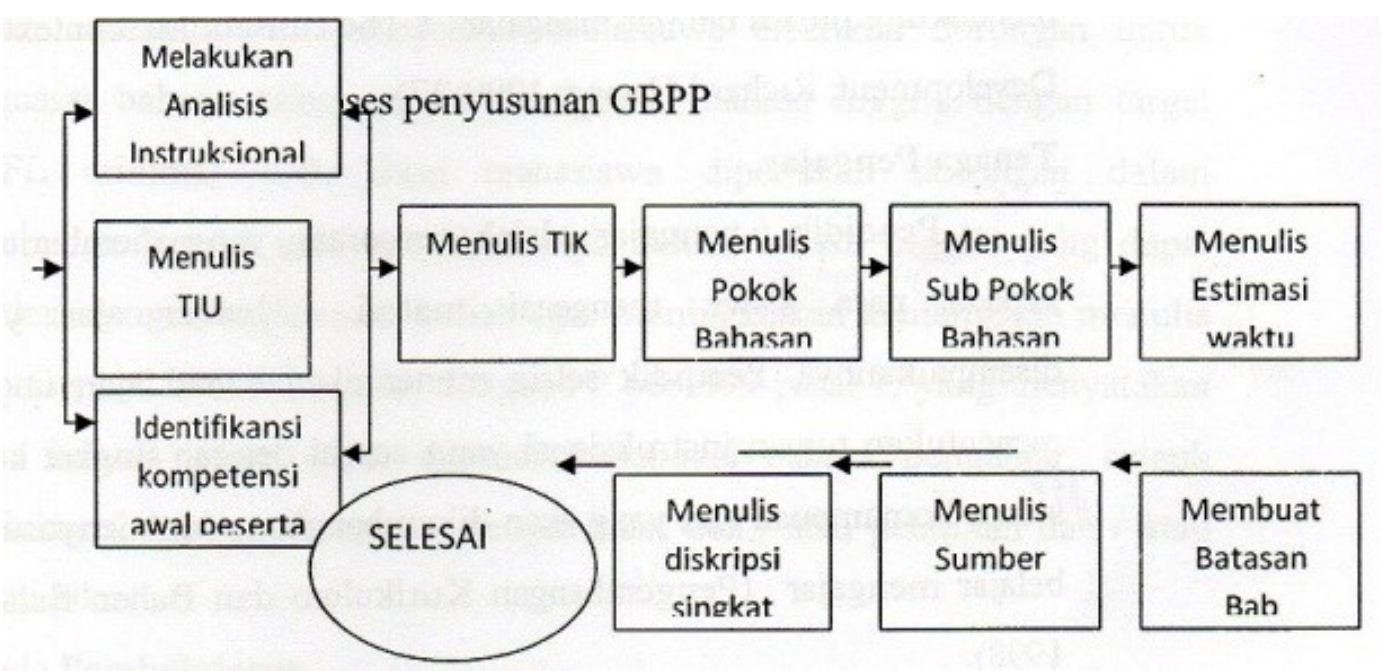


Menurut Dikmenjur (1999:4)

Kurikulum kompetensi ( Competency Based Curriculum) adalah kurikulum yang dikembangkan berdasarkan pada kompetensi-kompetensi yang dibutuhkan di industri dan tertuang dalam standar kompetensi sesuai dengan bidang keahlian yang relevan. Dalam pengertian lain kompetensi terdiri dari spesifikasi pengetahuan dan ketrampilan serta aplikasi dari pengetahuan dan ketrampilan itu dalam jabatan atau tingkat industri untuk standar kinerja yang dibutuhkan dalam pekerjaan.

Kompetensi lebih di fokuskan pada apa yang diharaplan dari seseorang karyawan di tempat kerja dari pada proses pembelajaran, dan mencakup kemampuan untuk menstranfer dan menerapkan pengetahuan dan ketrampilan yang dimiliki pada situasi dan lingkungan baru. Impelatasi kurikulum tidak kalah pentingnya dengan pengembangan isi kurikulum, sebaik-baik isi kurikulum tetapi jika tidak dilaksanakan dan dipahami dengan baik maka akan mengalami kegagalan. "Kurikulum ditentukan oleh letak masyarakat, sejarah kebudayaan . kurikulum tidak dapat dikembangkan tanpa adanya kegiatan tetapi dengan melalui proses yang berdasarkan pada kepercayaan yang sering membuat jelas tentang bagaimana orang-orang belajar, apa yang orang-orang sukai dan apa lingkungannya. Kurikulum jelas dengan susunan/struktur yang mendukung proses belajar mengajar" ( The curruculum: context, Design \& Development, Richard Hooper 199:27)

\section{Tenaga Pengajar}

Pendidik/pengajar adalah seseorang yang memberi penjelasan kepada para siswa mengenai materi/bahan ajar yang akan disampaikannya. Pendidik selain menentukan bahan ajar, ia juga harus menentukan tujuan instruksional yang sesuai dengan tingkat kemampuan siswa,kemampuan apa yang akan dikembangkan, dan menyusun keguiatan belajar mengajar (Pengembangan Kurikulum dan Bahan Belajar II, UT 1998).

Sedang berdasarkan keputusan Menpan Nomor 01/KEP/M.KEP/2001 tentang jabatan fungsional widyaiswara dan angka jreditnya, mendefinisikan widyaiswara yang berbunyi “Pegawai negri sipil” (PNS) yang diangkat 
sebagai pejabat fungsional oleh pejabat yang berwenang dengan tugas,tanggung jawab, wewenang untuk mendidik, mengajar, dan atau melatih PNS pada lembaga pendidikan dan pelatihan (Diklat) pemerintah.

\section{Bahan Ajar / Materi diklat}

Modul/bahan ajar adalah sarana/jenis bacaan yang disajikan untuk peserta diklat agar dapat memiliki panduan dalam peroses belajar mengajar. Pengembangan kurikulum dan bahan belajar II,UT (1998:18)

Menurut LAN (2002:iv) Modul-modul diklat berjenjang tingkat pertama disusun sebagai media untuk pembangunan dari sebagian kompetensi yang dipersyaratkan bagi pejabat fungsional widyaiswara.

Berkaitan dengan materi, Joetata Hadihardojo (2000) menyanrakn agar materi yang bersifat pembentukan ketakwaan terhadap tuhan YME, sikap, perilaku jujur, disiplin, hendaknya sarat di berikan sejak dari SD, SMP, SMU, makin ke atas makin berkurang (bukan ditiadakan) dan sampai dengan perguruan tinggi makin sarat akan muatan IPTEK. Di perguruan tinggi lebih ditekankan selalu IPTEK, bimbingan dalam etika bersosialisasi, berbisnis, berprofesi, serta kemampuan kerja tim,atau dalam bahasa lainsarat dengan muatan interdipilner. Selanjutnya mahasiswa diberikan dorongan untuk menguasai bahan asing, seperti menguasai bahasa inggris dengan target TOEFL minimal 450. Bagi mahasiswa diperlukan dorongan dlam kemampuan "report writing", khususnya dalam bahasa inggris yang dapat dikaitkan dengan tugas mata kuliah agar meningkatkan kemamouan menulis dan persentasi. Hal ini sejalan dengan PP 60/1999 pasal 7, yang menyatakan bahwa bahasa asing dapat digunakan sebagai bahasa pengantar, sejauh diperlukan dalam penyampaian pengetahuan dan/atau pelatihan dan/atau ketrampilan.

\section{Metode Pembelajaran}

Metode pembelajaran merupakan cara-cara / teknik yang dipergunakan oleh fasilitator / guru / widyaiswara dalam peroses pembelajaran agar tercapai tujuan instruksional yang diharapkan. 
Lebih lanjut dikatakan bahwa yang dimaksud dengan metode pembelajaran adlah cara atau alat untuk menciptakan hubungan antara peserta dan pengajar dalam peroses pembelajaran agar tercapai tujuan pembelajaran (LAN RI,2002:6).

Adapun jenis metoode pembelajaran yang dapat menghantarkan peserta diklat secara aktif adalah sebagai berikut :

1. Metode Kuliah (Lecture)

2. Metode Demontrasi

3. Kelompok studi kecil (bzz group)

4. Metode Diskusi

5. Metode Brainsroming

6. Metode Studi Kasus

7. Metode Bermain Peran (role play)

8. Metode Simulasi

9. Metode Seminar

\section{Sarana \& Prasarana}

Sarana \& prasarana proses belajar mengajar adlah segala sesuatu atau alat-alat yang dibutuhkan/ mendukung proses belajar mengajar. (://www.dikdasmen.depdiknas.go.id). Penyampaian pesan melaui media suara (audio) hanya mampu menjangkau daya ingat seseorang hanya 10-15\% saja, sedangkan apabila memakai media gambar atau memanfaatkan indera pengelihatan (video) mampu mengendap dalam ingatan sekitar 75-80\% apalagi kalau digabung menjadi media audio visual (Sasonoharjo, 2002:1). Adapun di era informasi saat ini suatu media pembelajaran sudah sangat maju yang dapat menyatukan beberapa media lainnya baik media tulisan, animasi, grafik dan dimodifikasi dengan media suara yang lebih dikenal dengan multi media system, bahkan dalam penerapannya dapat dipakai sebagai media jarak jauh dalam pembelajaran yang biasa disebut dengan distance learning atau tele conference, melaui jaringan internet dan WAN kota yang sedang dan telah dibangun di beberapa ibukota provinsi tentu saja hal ini 
memerlukan biaya yang besar dan perlu ditangani oleh SDM yang terampil dibidangnya.

Adapun media pembelajaran yang lain sangat lah beraneka ragam diantaranya:
a. Papan Tulis
b. Slide Proyektor
c. Papan Panel
d. Flip Chart
e. Overhead (OHP) Proyrktor / Tranparansi
f. LCD Proyektor / In Focus dan lain-lain .Berikut ini adlah sara infrastuktur yang diperlukan untuk berjalannya jaringan informasi sekolah yang harus disediakan untuk system pembelajaran WAN kota sebagai regioanal senter

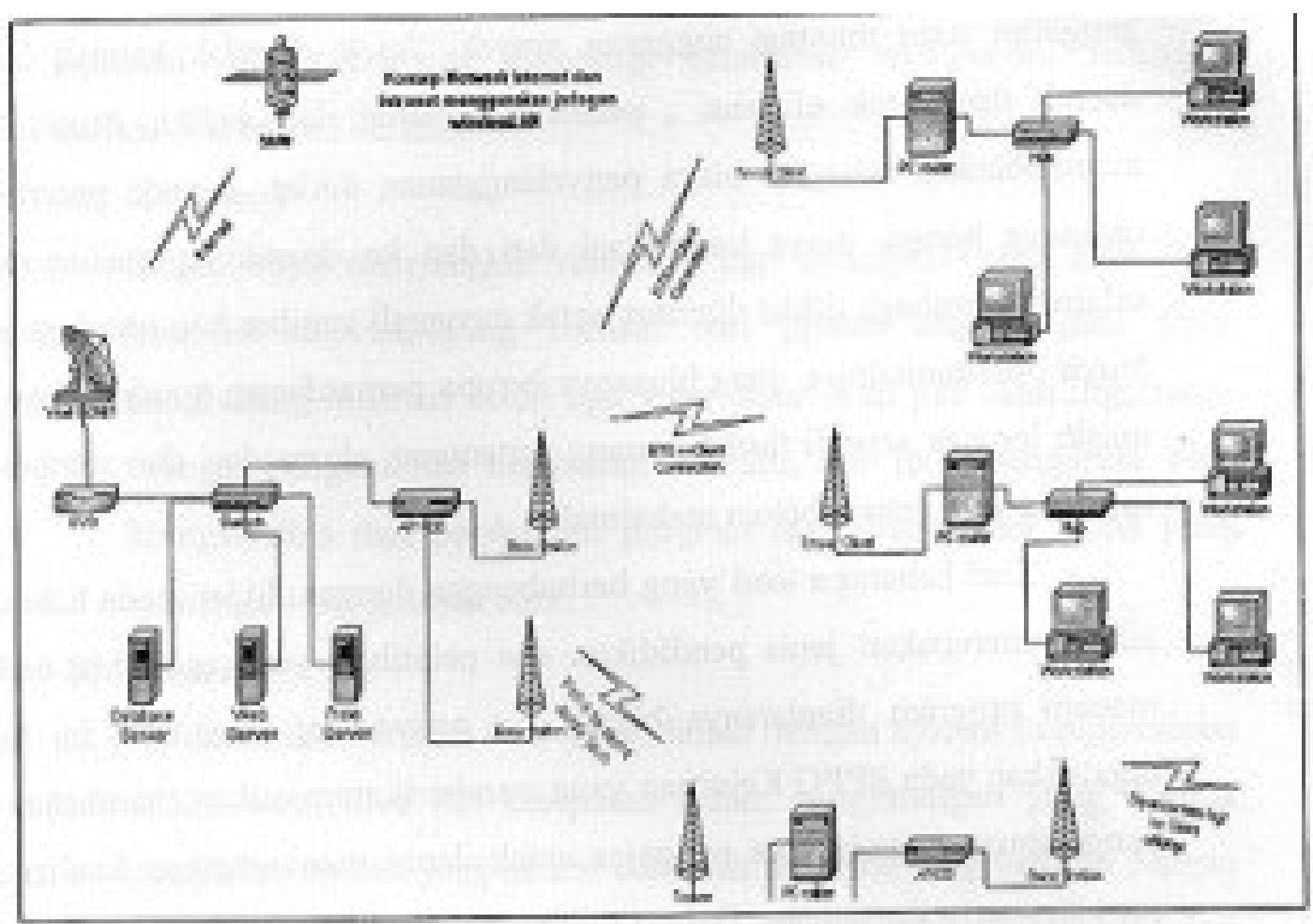

Gambar 8 : infrastruktur WAN kota Malang 


\section{Dana Anggaran / Biaya pendidikan}

Kesulitan utama pada akhirnya berkaitan dengan keterbatasan penyediaan anggaran biaya rutin, apalagi untuk pembangunan (investasi, lebih-lebih setelah terjadinya krisis moneter yabg berkepanjangan selama ini.

Tentang konsep biaya pendidikan menurut Nanang Fattah (2000:23) biaya dalam pendidikan meliputi biaya langsung (direct cost) dan biaya tidak langsung (Indirect cost). Biaya langsung terdiri dari biaya-biaya yang dikeluarkan untuk keperluan pelaksanaan pengajaran dan kegiatan belajar siswa berupa pembelian alatalat pelajaran, biaya transportasi, gaji guru, buku yang dikeluarkan oleh pemerintah,orang tua maupun siswa

sendiri. Sedangkan biaya tidak langsung berupa keuntungan yang hilang (earning forgone) dalam bentuk biaya kesempatan yang hilang (opportunity cost) yang dikorbankan oleh siswa selama belajar.

Biaya pendidikan dan latihan jika diterapkan untuk imstansi pemerintah, maka sebagian besar merupakan biaya anggaran pemerintah baik amggaran rutin maupun anggaran proyek. Sejak diberlakukannya otonomi daerah dan untuk efesiensi, pemerintah mulai dari sedikit demi sedikit membebankan sebagian biaya penyelengaraan diklat kepada peserta yang biasanya berupa biaya pemanfaatan sumber daya yang masih longgar seperti fasilitas ruang pertemuan, akomodasi dan sumber daya manusia yang masih belum maksimal.

Dari beberapa teori yang berhubungan dengan diklat, pada hakikatnya adalah merupakan jenis pendidikan dan pelatihan yang meiliki berbagai macam program diantaranya bisnis dan pariwisata, yang saat ini sedang digalakan pada PPG Kejuruan yang memberikan masukan / tambahan ilmu pengetahuan kepada para pengajar untuk dapat meningkatkan kualitas dari para siswa yang mana. Dalam tulisan ini di fokuskan pada sekolah-sekolah SMK. 


\section{Difinisi Operasional Variable dan Indikator}

Mengapa pada uraian rngksan teori dan konsep kunci tersebut diatas, maka dapat diidentifikasikan operasional variabelnya yang meliputi, dimensi dari hasil pengolahan penerapan teknologi informasi, fungsi pokok lembaga bisnis pada umumnya, dan pengaruhnya terhadap kebutuhan program diklat bidang bisnis dan pariwisata yakni sebagai berikut :

\section{Dimensi / Karakteristik Penerapan Teknologi Informasi}

Yang dimaksud dengan dimensi atau karakteristik penerapan teknologi informasi adalah menyangkut hasil atau output darin proses pengolahan data kegiatan suatu lembaga bisnis jika diolah dengan menerapkan teknologi informasi sebagai suatu alat bantunya dengan menggunakan

system informasi yang sudah dirancang sesuai dengan karakteristik bentuk usaha, dan jenis kegiatan data yang diolah sehingga menghasilkan informsi yang diharapkan dapat dipakai oleh manajer dan stake holder lainya sebagai pengambilan keputusan dalam rangka pencapaian target kinerjanya.

Dimensi dari penerapan teknologi informasi mempunyai beberapa indikator sebagai berikut:

\section{a. Relevensi}

Indikatornya menyangkut relevansi daro informasi yang dihasilkan haruslah relevan, yang berasal dari proses sumber data yang mendukung informasi detail apa yang diperlukan dika akan digunakan sebagai pengambilan keputusan tertentu, hal ini dipengaruhi oleh kompleksiats dari pembuatan program dan kinerja dari SDM yang menangani pengolahan data. 


\section{b. Akurasi}

Indikator dari akurasi data yang diolah dengansystem komputerisasi adalah keandalan dan ketepatan dalam perhitungan yang bekerja dengan ketepatan yang akurat dan oleh prosesor yang bekerja dengan aritmatik logical unit (ALU), justru disinilah kelebihan dari komputer yang dapat menghitung (to comput) dengan ciri tidak cepat mengalami kelelahan seperti manusia.

\section{c. Ketepatan Waktu}

Indikatornya terkait dengan seting komputer yang secara otomatis sudah ada tanggal dan real time yang ada dalam komputer itu sendiri, sehingga dalam hal ini selama proses input data tidak terlambat, maka informasi apapun dapat diperoleh dengan tepat waktu dan hasilnya akan tergantung dari data apa yang diperoses dan informasi apa yang diperlukan. Hal ini telah terbukti dan diterapkan pada perbaikan dengan mesin ATM Automatic Teller Machine) nasabah dapat mengambil uang di mesin yang ada di manapun dengan perhitungan yang sangat tepat, juga berlaku pada pengiriman surat E-mail saat itu dikirim dalam waktu yang sama akan sampai pada alamat penerima walaupun berjauhan jaraknya. Jika kita terlambat dalam mengambil keputusan yang ada pada hari itu ada perubahan harga dollar maka kita kehilangan kesempatan untuk mendapat manfaat.

\section{d. Kelengkapan}

Kelengkapan data yang diproses dengan system komputerisasi indikatornya adalah informasi sangat lengkap tergantung untuk keperluan siapa laporan informasinya sangat lengkap tergantung untuk keperluan siap laporan informasi tersebut, bagi manajer puncak dan untuk keperluan tahunan laporan bisa di tampilkan sangat ringkas ( misalnya laporan keuangan ), tetapi bagi manajer menengah ke bawah akan lebih detail bahkan sangat detail karena biasanya untuk laporan unit/bagian yang lebih kecil dan memerlukan data rinci. 


\section{Fungsi pokok dalam lembaga bisnis.}

Secara umum dungsi pokok lembaga bisnis dapat dibagi dalam empat bagian pokok besar hal ini biasanya disesuaikan dengan kebutuhan perusahaan, antara lain fungsi produksi / bagian operasional, fungsi pemasaran, fungsi administrasi dann umum dan fungsi akuntansi. Adapun indikator selengkapnya sebagai berikut.

\section{a. Fungsi Produksi}

Indikator penerapan teknologi informasi / komputerisasi dan otomatosaso yang berhubungan dengan fungsi produksi adalah sudah diterapkannya komputer sebagai alat bantu yang efesiensi dan mempercepat proses produksi baik dari kecepatan pengolahan produk maupun perhitungan biaya produksi mulai dari penanganan persediaan bahan mentah, absen pekerja sampai penagihan penentu haraga pokok produksi dan untuk penetapan harga jual produk, hal ini akan relevan dengan ketrampilan yang harus dimiliki dibidang bsisnis dan pariwisata utamanya perhitungan harga pokok pembuatan produk misalnya, Cost pembuatan baju cost dari katering, usaha jasa perhotelan dan juga untuk jurusan akuntansi yang akan bekerja menggunkan apliaksi akuntansi untuk menghitung haragapokok pembuatan produk.

\section{b. Fungsi Administrasi \& Umum}

Setiap lembaga bisnis selalu ada bagian yang menangani adminitrasi dan umum, penanganan bidang administrasi sebagian besar tidak lagi ditangani secara manual denngan adanya mesin komputer, baik untuk pengetikan surat resmi maupun pengiriman surat melalui elektronik atau E-mail sudah banyak ditetapkan di semua perkantoran yang modern, termasuk dalam hal system pengarsiapn surat penting dan data transaksi lainnya dengan sistem penyimpanan di Hardisk, Tape ware maupun pada Compact Disk, sehingga lebih ringkas, menghemat dan efesien serta mudah dicari. Jurusan administrasi di SMK perlu di perkenalkan dengan sistem yang baru ini, agar anak 
didik tidak ketinggalan teknologi yang berlaku di dunia kerja melalui diklat administrasi dan magang di industri.

\section{c. Fungsi Penasaran}

Indikator yang terjadi dalam fungsi pemasaran adalah telah diterapkannya teknologi informasi dalam rangka memperluas pasar untuk menigkatkan omset penjualan, hal ini bisa terlihat dari banyaknya situs web yang diterapkan untuk memasang iklan, baik malaui koran di virtual (ciber news) maupun yang dibangun sendiri dalam rangka memperkenalkan produk, yang sangat menarik yang berisi keunggulan produk kemudahan pemesanan, maupun pengiriman dan cara pembayaran yang tanpa harus bertemu dengan penjual dan kasir untuk pembayaran. Hal lain adalah dipakainya multi media sebagai alat pembuat iklan yang sangat menarik baik yang ditayangkan di TV maupun iklan bergerak untuk promosi pemasaran saat pameran produk dengan multi media yang sangat menari. Untuk ketrampilan ini siswa SMK terutama jurusan pemasaran dan SMK TI perlu dibekali dengan letrampilan multi media production,melalui diklat penataran guru dan berusaha untuk bisa menguasai ketrampilan yang baru melalui kursus-kusus non formal.

\section{d. Fungsi Keuangan \& Akuntansi}

Indikator yang berhubungan dengan bagian akuntansi adalah telah banyak diterapkannya teknologi informasi khususnya aplikasi akuntansi untuk memperoses data keuangan perusahaan, baik dengan software aplikasi yang dibangun sendiri, software dengan pesanan khusus (tailor made application) maupun software akuntansi yang dijual dipasaran umum seperti Dec Easy accounting, MYOB, General Ledger, Value plus dan masih banyak lagi produk yang dijual secara umum .beberapa tahun terakhir untuk menegetahui kompetensi ketrampilan siswa jurusan akuntansi telah diadakan lomba ketrampilan siswa seluruh indonesia baik dengan akuntansi manual maupun dikerjakan dengan komputerisasi, dan hasilnya sudah cukup 
mengembirakan walaupun dari beberapa daerah masih banyakmengalami kendala dan perlu adanya pemasyarakatan dan diklat khusus komputer akuntansi sebagai standarisasi ketrampilan kejuruan.

\section{Kebutuhan Diklat}

Kebutuhan diklat diperlukan sebagai dasar penentuan program diklat apa yang akan dilaksanakan pada tahun berjalan atau tahun yang akan datang berapa lamanya, untuk materi level berapa, siapa nara sumbernya, alat yang diperlukan dan siap yang akan diikutkan dalam program diklat tersebut pencapaian ketrampilan dibidang-bidang tertentu serta penentuan alternatif anggaran yang harus disiapkan. Hal yang perlu diperhatikan jugan adalah seberapa jauh penerapan teknologi dipakai di dunia kerja yang menyebabkan kesenjangan ketrampilan antara sekolah dan kebutuhan ketrampilan di dunia bisnis.

\section{a. Kurikulm}

Kurikulum yang dituntut sekarang indikatornya adlah kurikulum berbasis kompetensi (CBT) Competency Based Training baik berstandar nasional ataupun

berstandar internasional, dalam hal ini perancang kurikulum membutuhkan keterlibatan dunia kerja, yang telah terbentuk baik di tingkat pusat maupun daerah yang beranggotakan ikadin dan prakrisi di bidang masing-masing yang relevan. Dlam persiapannya diperlukan petunjuk pelaksanaanya yang persiapannya dapat dituangkan dalam garis-garis besar program pembelajaran (BGPP), satuan acara pembelajaran (SAP) dan bahan ajar, sehingga siapapun yang akan mengajarkannya telah ada bahan standar materi yang akan diberikan.

\section{b. Tenaga Pengajar}

Tenaga pengajar merupakan faktor penting dalam penyampaian materi kepada warga belajar (audience) untuk itu seorang 
pengajar dituntut untuk menguasai materi pembelajaran, metode mengajar yang disesuaikan dengan siapa audiencenya, juga gaya tampilan yang menarik, juga pengalaman sehingga wawasannya luas. Sehubung denganperkembangan teknologi seorang peajar dituntut untuk dapat mengguanakan teknologi yang ada dan dipersiapkan pada lembaga diklat, seperti cara penggunaan OHPnyang benar, dan afektif, penggunaan LCD yang dihubungkan dengan komputer animasi yang memerlukan sedikit ketrampilan agar penampilan tidak ketinggalan jaman dan lebih professional.

\section{c. Bahan Ajar (buku-buku)}

Bahan ajar diperlukan sebagai pedoman pemberian materi yang lebih detail dan dapat dipelajari kembali setelah berakhirnya diklat, hal yang perlu diperhatikan adalah dengan perkembangan teknologi buku sumber akan cepat usang karena perkembangan iptek yang cepat untuk itu perlu referensi buku baru sebagai acuan agar tidak ketinggalan, ada baiknya bahan ajar dibut yang praktis baik dalam bentuk modul ataupun karya tulis sebagai hand out bagi peserta diklat sehingga mudah dipahami dan ringkas, termasuk system evaluasinya. Di era teknologi internet bahan ajar sudah dapat dicari melalui internet dengan cara search engine dengan kata kunci tertentu sehingga apa yang dicari dan pernah dimuat di dunia maya akan didapatkan informasi sebagai pelengkap makalah yang up to date

\section{d. Metode Mengajar}

Beberapa indikator yang berhubungan dengan metode mengajar dapat dilihat dari antusias keaktivan peserta untuk mengikuti materi yang diberi dengan daya serap yang tinggi, banyak metode belajar yang dapat dipakai hal ini disesuaikan dengan siapa audiencenya, materi apa yang diberikan dan sarana ataupun alat bantu yang tersedia 
Dalam hubungannya dengan teknologi komputer. Lebih dituntut unyuk banyak praktek dengan penjelasan secukupnya melalui demo dengan LCD dan media animasi yang menarik, perlu juga dicoba dengan metode active learning sehingga audiencenya dapat mengembangkan dan berkreasi, dengan mencari sumber dari internet ataupun dengan system pakar.

\section{e. Sarana \& Prasarana PBM}

Tuntutan yang perlu diperhatikan dengan berkembangnya iptek adalah konsekuesi pada sarana dan prasarana yang perlu disesuaikan, sengan alat apa yang sekarang dipakai di dunia kerja baik software maupun hardwarenya, karena sekolah kejuruan tamatannya diharapkan telah menguasai ketrampilan yang dituntut dan menjadi kebutuhan dunia kerja, konsekuensinya adalah lembaga diklat kejuruan perlu melengkapi fasilitas yang mencukupi untuk menyesuaikan kesenjangan peralatan diklat.

\section{f. Dana / anggaran}

Dengan diterapkanya teknologi informasi mempunyai konsekuensi langsung terhadap kebutuhan dana, baik untuk pembelian hardware,software dan biaya yang langsung seperti pulsa tipun, tagihan listrik dan bahan habis lainnya seperti tinta printer dan kertas print, juga tenaga maintenance untuk perawatannya, hal ini yang biasanya belum direncanakan dengan tepat dalam system perencanaan anggaran diklat.

\section{g. Hasil Penelitian}

\section{DESKRIPSI DATA}

Dengan mendasarkan pada tujuan penelitian seperti yang telah diuraikan pada bab sebelumnya, dari sampelyang ditetapkan terhimpun data yang telah diisi oleh seponden, disini terdapat data umum tentang didepkrisi responden dan tiga macam variable data yang harus dianalisis. 
Sebelum menganalisis berbagai pendapat responden, penulis berpendapat bahwa data-data responden perlu dikemukakan terlebih dahulu sebagai pendukung analisis pokok selanjutnya.

Tabel 3

Usia Responden

\begin{tabular}{|l|l|r|r|}
\hline NO. & Usia & Frekkuensi & Presentase \\
\hline 1. & Dibawah 30 th & 12 & $12 \%$ \\
\hline 2. & 30 th. s/d 39 th. & 27 & $27 \%$ \\
\hline 3. & 40 th s/d 49 th & 36 & $36 \%$ \\
\hline 4. & 50 th. s/d 60 th. & 25 & $25 \%$ \\
\hline & jumlah & 100 & $100 \%$ \\
\hline
\end{tabular}

Sumber : Hasil tabulasi dari kuisioner

Dari informasi dalam tabel diatas dapat terlihat bahwa dari 100 responden cukup menyebar secara bervariasi, yang agak menonjol yaitu responden yang berumur 40 sampai dengan 49 tahun, 36 orang atau $36 \%$, sedang 27 orang (27\%) hingga berumur 30 tahun

Sedangkan dari sisi jenis kelamin dari data yang masuk setelah diolah menunjukan distribusi jenis kelamin laki-laki sebesar 36 orang dan jenis kelaminperempuan sebesar 37 orang hal ini dapat mengambarkan tenaga guru dan kependidikan yang umumnya tertarik dengan peralatan komputer lebih banyak dari laki-laki.

Dari 100 data yang diolah dari bidang pekerjannya menunjukan angka berikut ini : 
Tabel 4

Pekerjaan Responden

\begin{tabular}{|l|l|r|r|}
\hline NO. & Bidang pekerjaan & Frekkuensi & \multicolumn{2}{|l|}{ Presentase } \\
\hline 1. & Guru SMK & 48 & $48 \%$ \\
\hline 2. & Tenaga Struktural SMK & 12 & $12 \%$ \\
\hline 3. & Widya Iswara/instruktur PPPGK & 32 & $32 \%$ \\
\hline 4. & Tenaga Struktural SMK & 8 & $8 \%$ \\
\hline & Jumlah & 100 & $100 \%$ \\
\hline
\end{tabular}

Sumber : Hasil tabulasi dari kuisinoner

Dari informasi dalam tabel 2 diatas dapat terlihat bahwa dari 100 responden 48 responden merupakan guru SMK. 32 \% Tenaga pengajar PPPGK, $12 \%$ staf SMK dan $8 \%$ adalah staf PPPGK.

Sedangkan dari segi pengalaman kerja responden menunujukan data sebagai berikut

Tabel 5

Pengalaman kerja responden

\begin{tabular}{|l|l|r|r|}
\hline \multicolumn{1}{|l|}{ NO. } & Pengalaman kerja & Frekkuensi & Presentase \\
\hline 1. & Sapai 5 th. & 8 & $8 \%$ \\
\hline 2. & 6 th. s/d 10 th. & 32 & $32 \%$ \\
\hline 3. & 11 th s/d 20 th & 15 & $37 \%$ \\
\hline 4. & 21 th. s/d 30 th. & 8 & $15 \%$ \\
\hline & Diatas 31 & 100 & $8 \%$ \\
\hline & Jumlah & & $100 \%$ \\
\hline
\end{tabular}

Sumber : Hasil tabulasi dari kuisioner

Dari informasi dalam tabel diatas dapat terlihat bahwa dari 100 responden yang diolah dilihat dari pengalaman kerja responden didominasi pada masa pengalaman 
kerja antara 11 tahun sampai 20 tahun sebesar 37\% dan usia 6 sampai 10 tahun sebesar $32 \%$

Dilihat dari jenjang pendidikan tertinggi responden menunjukan data sebagai berikut

\section{Tabel 6}

Pendidikan terakhir responden

\begin{tabular}{|l|l|r|r|}
\hline NO. & Pendidikan terakhir & Frekkuensi & Presentase \\
\hline 1. & D3/sarmud & 10 & $10 \%$ \\
\hline 2. & S1 & 54 & $54 \%$ \\
\hline 3. & S2 & 35 & $35 \%$ \\
\hline 4. & S3 & 1 & $1 \%$ \\
\hline & Jumlah & 100 & $100 \%$ \\
\hline
\end{tabular}

Sumber : Hasil tabulasi dari kuisioner

Dari informasi dalam tabel diatas dapat terlihat bahwa dari qoo reponden yang diolah menunjukan 54 orang atau $54 \&$ berlatar pendidikan s1,35 orang atau $35 \%$ berlatar belakang pendidikan s2 yang umumnya adalah widyaiswara PPPGK 10\% D3 dan $1 \%$ berpendidikan $\mathrm{S} 3$.

Tampilan Grafik pendidikan reponden

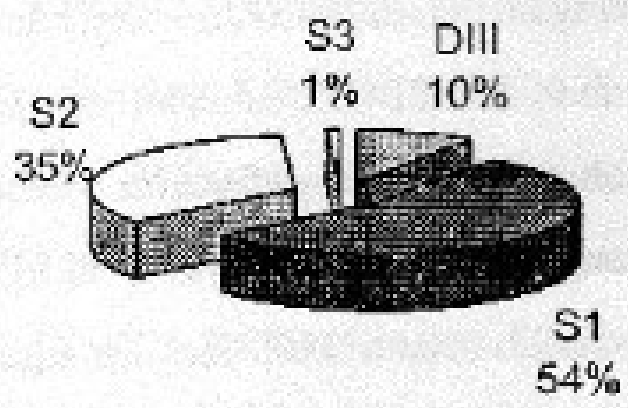

Gambar 10 : Grafik backround pendidikan 
Mengenai alamat e-mail dari 100 data yang diolah ternyata yang mempunyai alamat e-mail hanya sebesar 57 orang atau 57\% sedangkan 43\% tidak mengisi alamat email hal ini berarti sebagian besar guru telah memanfaatkan dan mengenal internet sedangkan sisanya belum memanfaatkan internet sebagai saran pengiriman informasi dalam hal ini elektronik mail.

Hasil olahan data yang berhubungan dengan ketrampilan menggunakan komputer menunjukan hasil sebagai berikut : Untuk ketrampilan menggunakan micrisoft office sebagian besar sudah dapat menggunakan walaupun belum mahir dan ada beberapa yang masih pemula sedangkan untuk menggunakan internet sebagian besar masih pemula dan hanya sedikit yang menyatakan mahir, untuk ketrampilan aplikasi bisnis sebagian besar masih pemula bahkan banyak yang tidak mengisi hanya ada beberapa yang menyatakan cukup memadai. Distribusi data pokok yang berhubungan dengan variable yang diteliti akan diuraikan lebih lengkap berikut ini.

Dimensi teknologi informasi (var. X1)

Fungsi Pokok Lemabaga Bisnis (var. X2)

Kebutuhan diklat guru SMK bidang bisnis dan pariwisata (var. Y)

Data-data tersebut diatas diperoleh dengan menggunakan kuesioner dan wawancara sebagai pelengkap analisi data yang disebarkan kepada para guru SMK yang mengajar mata pelajaran komputer di SMK yang mengikuti mailing lits dikmenjur dan guru SMk yang sedang mengikuti penataran di Pusat Pengembangan Penataran Guru Kejuruan Jakarta, serta para Widya iswara dan pejabat di PPPGK. Ukuran sampel sebesar 100 responden dari 1.200 guru yang pernah ikut penataran 3 tahun terakhir dan 200 karyawan PPGK golongan III dan IV yang aktif menggunakan komputer. Sampel penelitian dipilih secara acak. Hasil pengecekan data dan penskoran dari kuisioner yang masuk baik dari guru, widyaiswara maupun tenaga struktural dalam penelitian ini, dapat dihimpun data mengenai, dimensi dari penerapan teknologi informasi, Fungsi Pokok Lembaga Bisnis, dan Kebutuahan diklat Guru SMK yang disajikan dalam penjelasan berikut ini. 


\section{H. Kesimpulan}

Berdasarkan hasil pembahasan pada bagian-bagian sebelumnya khususnya dalam pokok bahasan pengujian hipopenelitian dengan teknik analisis statistik yang sudah baku memakai software SPSS, atas penelitian dari pengaruh penerapan teknologi informasi dan fungsi pokok lembaga bisnis terhadap kebutuhan diklat guru SMK di Pusat Pengembangan Penataran Guru Kejuruan (PPGK) Jakarta, penulis merangkum kesimpulan sebagai berikut :

1. Berdasarkan hasilanalisis dengan proses pengolahan data menggunakan SPSS maupun fungsi statistik dalam program spreadsheet excel variabel dimensi penerapan teknologi informasi (XI), hubungannya dengan kebutuhan diklat menunjukkan bahwa dari 10 item pertanyaan dengan rentang rekor terendah 10 dan rentang skor 50, berarti rentang nilai $=40$, dihasilkan informasi mengenai data 100 responden valid dengan nilai mean 40,6; median 41; dan mode 41. Ini menunjukkan bahwa hasilnya sangat baik atau karakteristik dar dimensi teknologi informasivsangat diperlukan untuk dipertimbangkan dalam kebutuhan diklat, dalam hal ini nilai median sama dengan nilai mode berada pada skor 41 masih diatas rata-rata (mean yang besarnya 40,60. Dilihat dari curve fit variabel dimensi TI terhadap kebutuhan diklat menunjukkan korelasi yang signifikan dengan hasil kurve linier dari kiri bawah ke kanan atas diikuti oleh penyebaran nilai observer yang mendekati garies linier meningkat sebanding dengan peningkatan kebutuhan kilat. 2) Variabel penerapan TI pada fungsi pokok lembaga bisnis (X2), hubungannya dengan kebutuhan diklat menunjukkan bahwa, hasil informasi mengenai data 100 responden valid dengan nilai mean 41,190; median 41.500; dan mode 42. Ini menunjukkan bahwa hasilnya sangat baik atau penerapan TI pada lembaga bisnis sangat diperlukan untuk dipertimbangkan dalam kebutuhan diklat, dalam hal ini Mean $<$ Median $<$ mode atau kurve juling ke kanan, dilihat dari curve fit variabel dimensi TI terhadap kebutuhan diklat menunjukkan korelasi yang signifikan dengan 
hasil kurve linier dari kiri bawah ke kanan atas diikuti oleh penyebaran nilai observer yang mendekati garis linier meningkat sebanding dengan peningkatan kebutuhan diklat. 3) hasil dari variabel kebutuhan diklat gutu (Y) sebagai variabel dependen, manunjukkan bahwa dihasilkan informasi mengenai data 100 responden valid dengan nilai mean 41,800; median 42.00; dan mode 43.00. ini menunjukkan bahwa hasilnya sangat baik atau kebutuhan diklat sangat diperlukan untuk menyesuaikan dari karakteristik/dimensi penerapan teknologi informasi dan juga penerapan TI pada lembaga bisnis, dalam hal ini mean $>$ median $<$ mode.

Dilihat variabel yang lain kebutuhan diklat lainnya lebih tinggi dari variabel bebas lainnya, hal ini dipengaruhi oleh hasrat untuk menyesuaikan kebutuhan diklat terhadap perkembangan TI, yang oleh responden dianggap sangat perlu untuk di perhatikan. 4) hasil pengujian correlasi dengan person correlation menunjukkan hasil yang signifikan hubungan dua variabel dengan variabel yang lainnya, dengan nilai:

a) Kebutuhan Diklat $\mathrm{Y}=(1.00) \mathrm{X} 1=(0,900) \mathrm{X} 2=(0,939)$

b) Dimensi TI X1 = (1.00); X2 = $(0,948) ; \mathrm{Y}=(0,900)$

c) Fungsi Bisnis $\mathrm{X} 2=(1,00) ; \mathrm{X} 1=(0,948) ; \mathrm{Y}=(0,939)$

Hal tersebut menggambarkan bahwa semua variabel saling berhubungan dan dua variabel yang lain signifikan dan saling memengaruhi.

Sedang secara parsial korelasi (partial correlation) menunjukkan hasil signigikansi untuk dua variabelnya dengan nilai:

a. X1 terhadap $\mathrm{Y}-1.000$, dan $\mathrm{X} 1$ terhadap $\mathrm{X} 2=0,6218, \mathrm{P}=0,409$

b. $\mathrm{X} 2$ terhadap $\mathrm{Y}=1,000$, dan $\mathrm{X} 2$ terhadap $\mathrm{X} 1=0,0839$.

Keduanya dinyatakan ada korelasi signifikan.

\section{Saran}

Berdasarkan kesimpulan seperti yang telah penulis kemukakan diatas mengenai pengaruh dimensi penerapan teknologi informasi dan penerapan 
teknologi fungsi pokok lembaga bisnis terhadap kebutuhan diklat guru SMK bidang bisnis dan pariwisat di PPPG Kejuruan Jakarta. Penulis mengajukan kepada pihak-pihak yang terkait baik kepada lembaga diklat maupun praktisi adalah sebagai berikut:

1. Mengingat karakteristik dari Dimensi penerapan teknologi informasi, pihak Pusat Pengembangan Penataran Guru Kejuruan (PPPGK), sudah saatnya memanfaatkan teknologi informasi secara lebih berdaya guna untuk menuju efisiensi dan efektifitas kinerja. Dengan penerapan teknologi informasi pengambilan keputusan akan ditunjang dengan informasi yang relevan, akurat, tepat waktu dan kelengkapan data, hal ini akan terlaksana jika sistem pengolahan data diklat dilaksanakan dengan baik.

2. Penerapan sistem informasi manajemen perlu didukung dengan software aplikasi yang relevan dengan lisence resmi, baik dari software hause ataupun dibangun sendiri. Juga perlu ditunjang dengan sumber daya manusia yang kompeten dan dianggarkannya dana operasional yang cukup memadai.

3. Diperlukan program magang karyawan dan para peserta diklat pada lembaga bisnis yang relevan, untuk mengejar ketertinggalan kompetensi apa saya yang dituntut dengan diterapkannya teknologi informasi pada fungsi pokok lembaga bisnis yang telah menerapkan Ecommerce

4. Untuk memenuhi kebutuhan diklat diperlukan kerja sama dalam penyelenggaraan dijlat dengan institusi lain yang relevan, baik dengan cara outsousing maupun mengadakan perjanjian kerja sama dengan pihak industri dalam rangka peningkatan kompetensi mutu sumber daya manusia.

5. Perlu dibangun standar sistem informasi manajemen (SIM) diklat yang dapat berlaku secara nasional, agar informasi dari unit lembaga pendidikan dapat saling sharing dengan unit lembaga pendidikan yang lain, hal ini perlu dikoordinasi sampai kementrian pendidikan nasional. 
